Bangladesh J. Plant Taxon. 27(2): 205-211, 2020 (December)

(C) 2020 Bangladesh Association of Plant Taxonomists

\title{
UTRICULARIA ROSETTIFOLIA ALFASANE \& HASSAN SP. NOV. (LENTIBULARIACEAE) - A NEW SPECIES FROM BANGLADESH
}

\author{
Md. Almujaddade Alfasane ${ }^{1}$, Md. Abul Hassan and Rauf Ahmed Bhuiyan \\ Department of Botany, University of Dhaka, Dhaka 1000, Bangladesh
}

Keywords: Utricularia rosettifolia Alfasane \& Hassan sp. nov.; New species, Lentibulariaceae; Bangladesh.

\begin{abstract}
A new species, Utricularia rosettifolia Alfasane \& Hassan (Lentibulariaceae), is described with illustration. Detailed taxonomic description including information on type specimens, flowering and fruiting time, ecology, and distribution in Bangladesh are provided. The diagnostic characters of this species and comparison with its closest one are also provided.
\end{abstract}

\section{Introduction}

Utricularia L., an insectivorous genus distributed throughout the world with the highest species richness in the tropical regions, comprises of 214-220 species (Taylor, 1989; Barthlott et al., 2004; Müller and Borsch, 2005). So far known, the freshwater Lentibulariaceae of Bangladesh is represented by nine species, namely Utricularia aurea Lour., U. bifida Linn., $U$. caerulea Linn., $U$. foliosa L., U. geminiscapa Benj., U. gibba Linn., U. inflexa Forsk., $U$. minutissima Vahl, and U. scandens Benj. (Hooker, 1888; Prain, 1903; Datta and Mitra, 1953; Khan and Halim, 1987; Uddin et al., 2000; Rahman, 2005; Ahmed, 2009; Alfasane et al., 2020).

While exploring aquatic macrophytes throughout Bangladesh, we got one interesting Utricularia specimen which after critical examination and survey of the relevant documents and literature, appears to be different from all other species of the genus known previously. Morphologically it seems apparently similar and closely related to Utricularia geminiscapa Benj., from which it is clearly distinct.

\section{Materials and Methods}

The plant materials of this bladderworts were collected from the Joydia baor, Safdalpur union of Kotchandpur upazila of Jhenaidah district of Bangladesh through a hydrobiological expedition carried out from February 2019 to October 2020. This baor is an oxbow lake, usually generated due to the change of the direction of the river. Joydia baor is one of the large baors of Bangladesh in respect of area and fish production. It is located between the latitude $23^{\circ} 26^{\prime} 40.6^{\prime} \mathrm{N}$ and longitude $88^{\circ} 55^{\prime} 47.4^{\prime \prime} \mathrm{E}$. Total area of the baor is around 2.16 square kilometers. The minimum depth is $3.27 \mathrm{~m}$ at its southern part and the maximum depth is $9.7 \mathrm{~m}$ at the eastern part of its middle portion. It is a perennial water body and mostly rain fed. Well managed aquaculture has been carried out in the baor. The sample was collected from $0.5 \mathrm{~m}$ depth of the littoral area of the baor. The collected plant samples was then put in a large air tight ice bag with some water inside. It was then transported to the Phycology, Limnology and Hydrobiology Laboratory, Department of Botany, University of Dhaka. Some materials were preserved as a herbarium sheet in this laboratory. The remaining plant samples were planted in a concrete house $(1 \times 0.5 \mathrm{~m}$ length, depth $0.40 \mathrm{~cm}$ ) in the Botanical Garden, Department of Botany, University of Dhaka, for ex-situ conservation and further detailed study.

${ }^{1}$ Corresponding author, E-mail: mujaddade@yahoo.com 
The holotype of the species is housed at the Bangladesh National Herbarium (DACB) and the isotype is preserved at the Herbarium of Phycology Limnology and Hydrobiology Laboratory, Department of Botany, University of Dhaka.

\section{Results and Discussion}

After critical studies, the new specimens of Utricularia are finally designated as a new species under the name Utricularia rosettifolia Alfasane \& Hassan. Taxonomic diagnosis, detailed description, photographs, illustration and other relevant information are provided below (Figs 1-3).

Utricularia rosettifolia Alfasane \& Hassan sp. nov.

(Figs 1-3)

Diagnosis: $U$. rosettifolia Alfasane \& Hassan is very closely related to $U$. geminiscapa Benj. due to the presence of cleistogamous and chasmogamous flowers together but it can be easily differentiated from $U$. geminiscapa by its whorled and rosette leaves; bracts two and opposite; two-lipped petals where the upper lip (up 5 to $8 \mathrm{~mm}$ ) is longer than the lower lip (up to 3 to 6 $\mathrm{mm}$ ); unequal and more than $1.8 \mathrm{~mm}$ long sepals (Table 1).

Holotype: Bangladesh, Jhenaidah district, Joydia baor, M.A. Alfasane, 1686(PLHL), 19.02.2019; Acc. No. 63594 (DACB)

Isotype: Bangladesh, Jhenaidah district, Joydia baor, M.A. Alfasane, 1686 (PLHL), 19.02.2019; Herbarium of Phycology Limnology and Hydrobiology Laboratory, Department of Botany, University of Dhaka

\section{Bengali name: Jolojojhajhi}

Aquatic herbs, perennial, suspended, free floating just below water surface, glabrous. Rhizoids absent or any other structure that can anchor the plant. Stolons filiform, sparingly branched; green, up to $65 \mathrm{~cm}$ long, leafy, internodes 7-15 mm long. Leaves whorled and rosette, foliar divisions terete, cut into thread-like segments, appearing as peacock feather, leaves 10-30 $\mathrm{mm}$ long, divided, each of the divided parts may be further divided, each divided into numerous secondary segments, forked 3-7 times, minutely and sparsely setulose. Traps numerous, less than $2 \mathrm{~mm}$ across, traps attached with most of the leaves by a short stalk; entrance, or door, or mouth is circular or oval flap, sometimes lateral, extending and curving down; at the dorsal position of the entrance one pair of branched antennae $(388 \mu \mathrm{m})$, long and short mucilage glandular hair, spine like trigger cells $(232 \mu \mathrm{m})$, several trigger hairs in the central region (across dia, 240-350 $\mu \mathrm{m}$ ); traps wall very thin and transparent, inflexible, upper half and lower half are very flexible by yielding effective hinge, soft stretches helps to seal the door; in the entrance-way of the bladders, there are also secretory (mucilage) hairs that vary in size $(85-115 \mu \mathrm{m} \times 9-15 \mu \mathrm{m})$; each hair possess a stalk, neck cell and a capital or terminal cell; different algae and diatoms are attached with the bladders. Inflorescences recemose, 2-5 flowered. Scales absent. Bracts 2, opposite, attached to the base, lanceolate, $1.5 \mathrm{~mm}$ long, apex acute, base round. Bracteoles absent. Flowers pedicellate, pedicels arise directly from the stolon, green, deflexed, up to $15 \mathrm{~mm}$ long, flowers are of two types, non-opening cleistogamous that remain submerged and fully opening chasmogamous that rise above the water, snapdragon-like flowers emerging from the water, nonopening flowers are borne singly on relatively short and thick stalks, up to $10 \mathrm{~mm}$ long, lacking of petals. Sepals unequal, green to yellowish green, oblong, convex with apex rounded, $1.8-2.5 \mathrm{~mm}$ long, upper lobe c. $2.5 \mathrm{~mm}$ long, $1.8 \mathrm{~mm}$ wide, oblong, convex with apex rounded; lower lobe c. $1.8 \mathrm{~mm}$ long, $2.2 \mathrm{~mm}$ wide, ovate with apex rounded. Petals yellow, two-lipped, upper lip 
distinctly longer ( 5- $8 \mathrm{~mm}$ ) than lower lip (3-6 mm), lower lip depressed obovate, with an inflated pouch at the base, i.e. palate, palate raised, pubescent with a marginal rim; spur present below the lower lip, shorter $(2.5-5.5 \mathrm{~mm})$ than the lower lip. Staminal filaments almost straight or slightly curved, c. $1 \mathrm{~mm}$ long, anther thecae confluent, pollen grains small $(16 \mu \mathrm{m})$, spherical. Style short, lower lip of stigma semicircular, shortly ciliate, upper lip obsolete, ovary globose (1 $\mathrm{mm}$ ), ovules with reticulate integument. Capsule globose, 1-2 $\mathrm{mm}$ in diam. Seeds numerous, dorsiventrally compressed, globose, $0.4-0.5 \mathrm{~mm}$ diam., $0.2-0.3 \mathrm{~mm}$ high, the testa cells irregular. Bud or Turions form at branch tips in September to November, turion formed at the growing tip of each stem, buds rounded, green and elongate up to $5 \mathrm{~mm}$ in diameter with small and slender leaves.

Flowering and fruiting: July to October.

Ecology: Grows on water surface in the littoral zones.

Distribution in Bangladesh: South-western districts of Bangladesh.

This new species is apparently morphologically similar to $U$. geminiscapa Benj. among the known species of Utricularia. The differences between $U$. geminiscapa and $U$. rosettifolia are outlined in Table 1.

Table 1. The major morphological differences between two species of $U$. geminiscapa Benj. and $U$. rosettifolia Alfasane \& Hassan.

\begin{tabular}{ll}
\hline U. geminiscapa Benj. & U. rosettifolia Alfasane \& Hassan sp. nov. \\
\hline (a) Leaves alternate & (a) Leaves whorled and rosette \\
(b) Bract 1 & (b) Bracts 2 \\
(c) The upper lip is slightly shorter than & (c) The upper lip is more than 1.5 times longer than the \\
lower lip & (d) Sepals unequal, $\geq 1.8 \mathrm{~mm}$ in length \\
(d) Sepals equal, c. $0.75 \mathrm{~mm}$ in length. &
\end{tabular}

Specimens examined: Jhenaidah: Joydia baor, M.A. Alfasane, 1686(PLHL), 19.02.2019; 1687(PLHL), 18.11.2019; 1688(PLHL), 19.02.2020; 1689(PLHL), 17.08.2020; 1690(PLHL), 10.10.2020, Dhaka: Botanical Garden, Department of Botany University of Dhaka (originally collected from Joydia baor, M.A. Alfasane 1686(PLHL), 19.02.2019).

Etymology: The species is named after its rosette arrangement of leaves.

Conservation status: Collected only from a single locality of Joydia baor, of Jhenaidah district. Excessive fishing, over harvesting, siltation, construction of flood control embankments, uncontrolled use of pesticides and chemical fertilizers, excessive removal of surface water and extraction of groundwater for irrigation, diversion of water courses, poor monitoring etc. are the main threats to the existence of this new species. No conservation initiative is yet undertaken. Therefore, both in situ and ex situ conservation measures are strongly suggested for existence of this new species. 

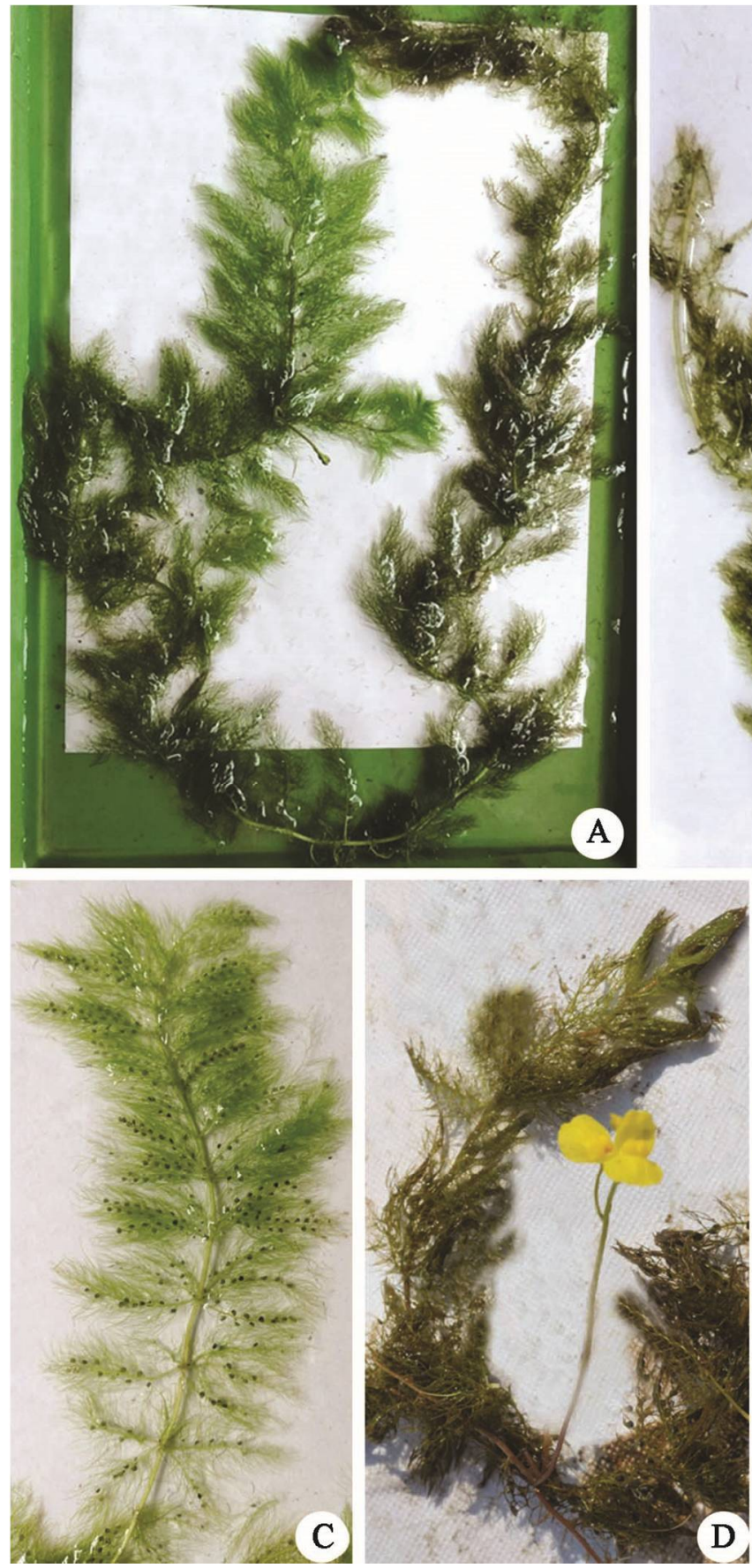


Fig. 1. A-H. A. Sparingly branched U. rosettifolia Alfasane \& Hassan. B-C. Rosette and whorled leaves. D. Pedicel with two open flowers directly arise from the stolon. E. Leaves divided into secondary segments, 3-7 times forking. F. Two flowers: one is front view, another is lateral view (left side). G. Winter bud. H. Matured bladders with densely forked leaves. 



Fig. 2. A-G. A. Traps of U. rosettifolia Alfasane \& Hassan in lateral view. B. Trap with a short stalk and mouth extending and curving down over the entrance. C. Dorsal view of the entrance showing one pair of branched antennae, mucilage glandular hair, spine like trigger cells. D-E, Soft stretches helps to seal the door with flexible upper and lower half by yielding effective hinge. F-G. Secretory (mucilage) hairs on the entrance. Scale Bar: A-B $=1 \mathrm{~mm} . \mathrm{C}-\mathrm{G}=100 \mu \mathrm{m}$. a: antennae, c: capital cell, d: door, g: gland hairs, s: stalk of bladder trap, t: trigger hairs, n: neck cell, st: stalk of gland hair. 


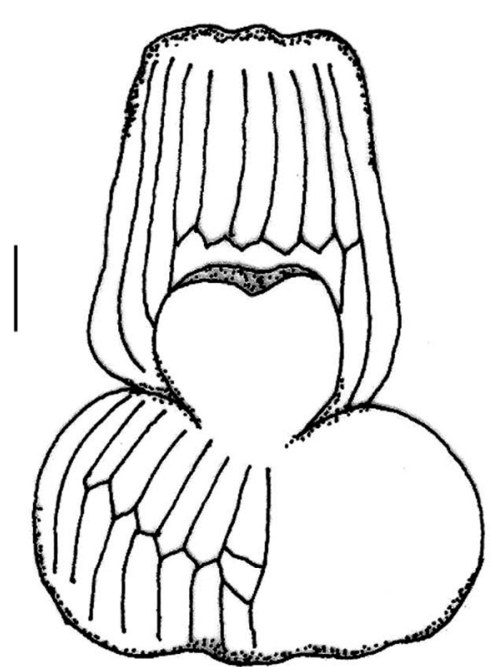

A

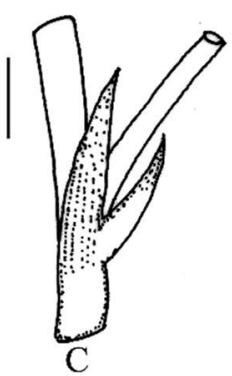


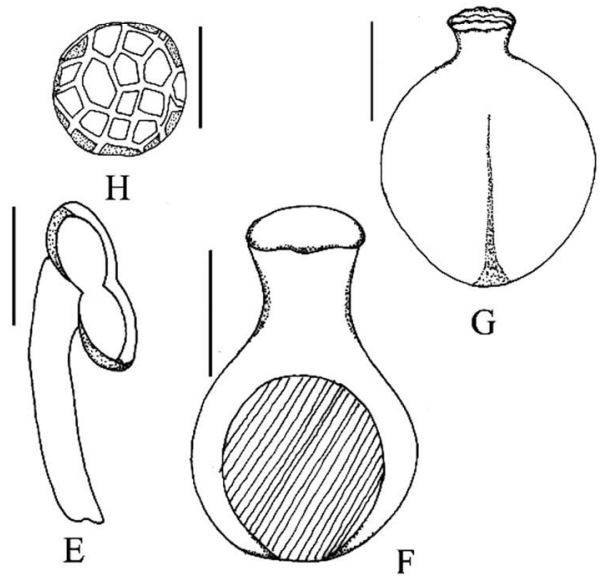

$\mathrm{H}$

Fig. 3. A-H. A. Flower in front view of $U$. rosettifolia Alfasane \& Hassan with upper and lower lip. B. Lower lip with spur in lateral view. C. Bracts with pedicel base. D. Calyx in dorsal view. E. Stamen. F. Pistil. G. Capsule. H. Seed. Scale bar: A-B $=2 \mathrm{~mm} ; \mathrm{C}, \mathrm{D}=1 \mathrm{~mm} ; \mathrm{E}-\mathrm{H}=0.5 \mathrm{~mm}$.

\section{Acknowledgements}

The authors express their heartfelt gratitude to Professor Dr. Saleh Ahammad Khan, Department of Botany, Jahangirnagar University, Savar, Dhaka for his critical comments, suggestions, encouragement and help during the final preparation of the manuscript. Authors are very much grateful to Mr. Abdur Rahim, Technical officer, Department of Botany, Jahangirnagar University, Savar, Dhaka for drawing the illustrations and Anik Biswas for his nice cooperation during sample collections.

\section{References}

Ahmed, Z.U., Hassan, M.A., Begum, Z.N.T., Khondker, M., Kabir, S.M.H., Ahmad, M., Ahmed, A.T.A., Rahman, A.K.A. and Haque, E.U. (eds.) 2009. Encyclopedia of flora and fauna of Bangladesh. vol. 8, Angiosperms: Dicotyledons (Fabaceae-Lythraceae). Asiat. Soc. Bangladesh, Dhaka. 478 pp.

Alfasane, M.A., Bhuiyan, R.A. and Eusufzai, M.K. 2020. Utricularia geminiscapa Benj. (Lentibulariaceae): A new angiospermic record for Bangladesh. Bangladesh J. Plant Taxon. 27(1): 191-194. 
Barthlott, W., Porembski, S., Sein, R. and Theisen I., 2004. Karnivoren: Biologie und Kultur Fleischfressender Pflanzen. Ulmer, Stuttgart. 224 pp, ISBN: 38001414429783800141449.

Datta, R.M. and Mitra, J.N. 1953. Common plants in and around Dacca. Bull. Bot. Soc. Beng. 7(1\&2): $1-110$.

Hooker, J.D. 1888. Flora of British India, vol.5. L. Reeve \& Co. Ltd., Kent, England. pp. 463-686.

Khan, M.S. and Halim, M. 1987. Aquatic angiosperms of Bangladesh. Bangladesh National Herbarium, BARC, Dhaka. 120 pp.

Müller, K. and Borsch, T. 2005. Phylogenetics of Utricularia (Lentibulariaceae) and molecular evolution of the $\operatorname{trnK}$ intron in a lineage with high substitutional rates. Plant Syst. Evol. 250: 39-67. https://doi.org/10.1007/s00606-004-0224-1.

Prain, D. 1903. Bengal Plants. Volume 2. Indian reprint 1963. Calcutta.

Rahman, M.O. 2005. A taxonomic account of Utricularia Linn. from Bangladesh. Bangladesh Journal of Plant Taxonomy, 12(2), 63-70.

Taylor, P. 1989. The genus Utricularia - a taxonomic monograph. Kew Bull. Add. Ser XIV : 1-724. HMSO, London.

Uddin, M.Z., Khanam, K., Hassan, M.A. and Khan, M.S. 2000. Utricularia minutissima Vahl (Lentibulariaceae) - A new angiospermic record for Bangladesh. Bangladesh Jour. Plant Taxon. 7(1): 65-67.

(Manuscript received on 14 June 2020; revised on 18 November 2020) 